\title{
Contribution of dose and frequency of administration to the therapeutic effect of growth hormone
}

\author{
P J SMITH, P C HINDMARSH, AND C G D BROOK \\ Endocrine Unit, Middlesex Hospital, London
}

SUMMARY Forty two prepubertal children who were growth hormone insufficient were treated for the first time with 12 IU of biosynthetic methionyl growth hormone a week in three subcutaneous regimens for one year after one year of pretreatment observation. Thirteen received 4 IU growth hormone three days a week (group 1), 21 received 2 IU six days a week (group 2), and eight received 1 IU twice daily six days a week (group 3). The mean (SD) changes in height velocity standard deviation score (SDS) were $+3 \cdot 8(1 \cdot 7)$ in group $1,+5 \cdot 3(2 \cdot 6)$ in group 2 , and $+5.9(2.7)$ in group 3 . There was a highly significant relation between the change in height velocity SDS and pretreatment height velocity SDS with a significant difference between the response of subjects receiving $<15 \mathrm{IU} / \mathrm{m}^{2} /$ week or $>15 \mathrm{IU} / \mathrm{m}^{2} /$ week growth hormone. Age, bone age, height SDS, and height for bone age SDS did not contribute to the prediction of response during the first year of treatment.

We recommend that growth hormone should be given in a dose of at least $15 \mathrm{IU} / \mathrm{m}^{2} /$ week by equally divided daily subcutaneous injections.

Growth hormone treatment is effective in initially increasing and subsequently maintaining the growth velocity of children who secrete little growth hormone and grow poorly as a consquence. ${ }^{1}$ Several groups have tried to elucidate the parameters that influence the growth response to treatment, which include the dose of growth hormone and frequency of administration, pretreatment growth velocity, age, bone age, height at the start of treatment and degree of growth hormone insufficiency. ${ }^{1-8} \mathrm{Al}-$ though both dose and frequency of administration have been considered important, the effects of these on growth response have not been adequately investigated. ${ }^{2} 5$ 9-11 Growth hormone secretion increases with age, stature, and puberty, which suggests that a varying dose will be required to optimise growth. ${ }^{12-15}$
The aim of this study was to investigate the contribution of various parameters of growth as well as dose and frequency of growth hormone administration to its therapeutic effect over the first year of treatment after the administration of biosynthetic methionyl growth hormone (Somatrem).

\section{Methods}

Altogether 42 naive prepubertal children who were growth hormone insufficient (31 boys, 11 girls) received Somatrem, (Somatonorm, KabiVitrum) for 12 months between January 1986 and March 1987 (table 1). Growth hormone insufficiency was diagnosed by analysis of growth velocity (height velocity SDS $<-0.8$ ) over a minimum period of one year and the growth hormone response to insulin

Table 1 Pretreatment clinical data. Results are mean (SD)

\begin{tabular}{|c|c|c|c|c|c|c|}
\hline & $\begin{array}{l}\text { No of } \\
\text { children }\end{array}$ & $\begin{array}{l}\text { Age } \\
\text { (years) }\end{array}$ & $\begin{array}{l}\text { Bone age } \\
\text { (years) }\end{array}$ & $\begin{array}{l}\text { Height } \\
S D S\end{array}$ & $\begin{array}{l}\text { Height for } \\
\text { bone age } \\
\text { SDS }\end{array}$ & $\begin{array}{l}\text { Height velocity } \\
S D S\end{array}$ \\
\hline Group 1* & 13 & $9 \cdot 6(2 \cdot 3)$ & $7 \cdot 5(2 \cdot 3)$ & $-2 \cdot 2(0 \cdot 5)$ & $-0.8(2 \cdot 6)$ & $-1.6(1.2)$ \\
\hline Group $2+$ & 21 & $8 \cdot 0(2 \cdot 5)$ & $6 \cdot 3(2 \cdot 1)$ & $-2.5(0.7)$ & $-0.9(1.6)$ & $-1.8(1.0)$ \\
\hline Group $3 \ddagger$ & 8 & $8.5(3.6)$ & $6 \cdot 0(2 \cdot 6)$ & $-2.7(1.0)$ & $-0.2(1.6)$ & $-2.6(1.4)$ \\
\hline Overall & 42 & $8 \cdot 6(2 \cdot 8)$ & $6 \cdot 6(2)$ & $-2.4(0.9)$ & $-0.7(1.8)$ & $-1.9(1.2)$ \\
\hline
\end{tabular}

Growth hormone given *4 IU three times a week; $\nmid 2$ IU six times a weck; and $\ddagger 1$ IU twice daily six times a week. 
induced hypoglycaemia $(0 \cdot 15$ units $/ \mathrm{kg}$ ) (maximum growth hormone concentration $<20 \mathrm{mU} / \mathrm{l}$ ) combined with thyroid releasing hormone $(200 \mu \mathrm{g})$ and luteinising hormone releasing hormone $(100 \mu \mathrm{g})$. Four children had multiple pituitary hormone deficiencies and were on appropriate replacement treatment.

The first 30 children were randomly allocated to one of three subcutaneous regimens. Group 1 received 4 IU growth hormone three times a week, group 2, 2 IU six times a week, and group 3, 1 IU twice daily six times a week. Two children in group 3 transferred to group 1 and one child from group 2 to group 1 during the first month of treatment because of practical difficulties. The remaining 12 children were allocated to group 2.

Anthropometric assessment was made at intervals of three months by the same observer using standard techniques, and bone age was assessed before and at the end of 12 months. ${ }^{16} 17$ The growth parameters were defined as standard deviation scores (SDS) as described by Tanner et al. ${ }^{18}$

Insulin like growth factor 1 was measured by the method of Baxter et al. ${ }^{19}$

Analysis of variance was used to test differences between the mean responses of the three treatment regimens. The results were then analysed using multiple regression analysis using the parameters of table 1 , dose $/ \mathrm{m}^{2}$ body surface area/week, and change in height velocity SDS. Significance was taken at the level of $p<0 \cdot 05$.

\section{Results}

There was no significant difference between the groups for pretreatment age, bone age, height SDS, height for bone age SDS, or height velocity SDS (table 1). All children in the three groups responded to growth hormone replacement with a highly significant change in height velocity SDS (mean (SD) change $+5 \cdot 0(2 \cdot 6), \mathrm{p}<0 \cdot 001)$ (fig 1). There was no significant difference in the mean change in height velocity SDS between the groups although there was a positive trend towards the higher frequency regimens (group 1, $+3.8(1.7)$; group 2, $+5 \cdot 3(2 \cdot 6)$; group $3,+5 \cdot 9(2 \cdot 7)$. The height gain achieved was not at the expense of inapproriate advance in bone age in any group with a significant improvement in height SDS for bone age occurring in all groups $(p<0 \cdot 04)$.

To determine the contributory factors involved in the first year of growth hormone replacement, the auxological parameters of table 1 and dose of growth hormone $/ \mathrm{m}^{2} /$ body surface area/week were analysed by multiple regression analysis. The groups were taken together as analysis of variance showed no significant differences in the response to the three dosage regimens nor in degree of growth hormone insufficiency as defined by the pretreatment height velocity SDS.

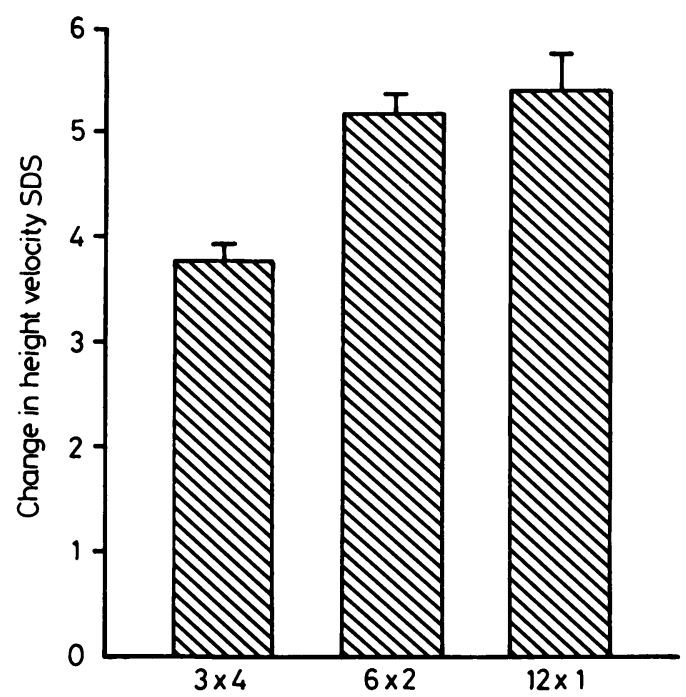

Fig 1 Response after one year of growth hormone treatment. Results are mean (SEM).

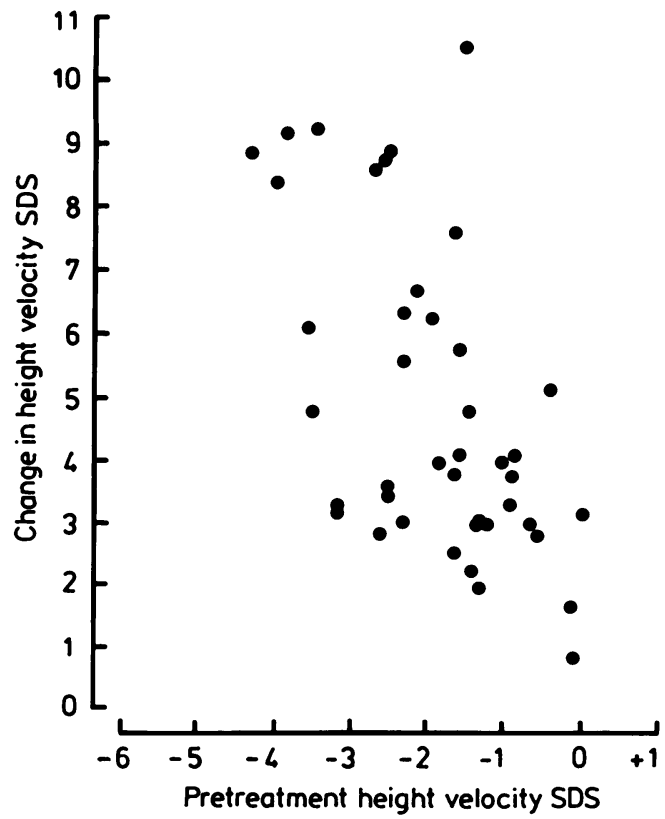

Fig 2 Change in height velocity SDS in relation to the pretreatment height velocity $S D S$ in 42 children $(r=-0.55, p<0 \cdot 001)$. 
Table 2 Effect of pretreatment height velocity and dose of growth hormone on change in height velocity over one year

\begin{tabular}{|c|c|c|c|c|c|c|}
\hline \multirow{2}{*}{$\begin{array}{l}\text { Height velocity SDS } \\
\text { (pretreatment) }\end{array}$} & \multicolumn{2}{|c|}{$<-1$} & \multicolumn{2}{|c|}{-1 to -2} & \multicolumn{2}{|c|}{$<-2$} \\
\hline & $(n=4)$ & $(n=8)$ & $(n=7)$ & $(n=7)$ & $(n=13)$ & $(n=3)$ \\
\hline $\begin{array}{l}\text { Dose growth hormone/ } \\
\mathrm{m}^{2} / \text { week }\end{array}$ & $<15$ & $>15$ & $<15$ & $>15$ & $<15$ & $>15$ \\
\hline $\begin{array}{l}\text { velocity SDS (SD) } \\
\text { p Value }\end{array}$ & $+2 \cdot 1(1 \cdot 1)$ & $2^{+3 \cdot 5(0 \cdot 8)}$ & $+3.6(1.4)$ & $+4.2(1.7)$ & $+5 \cdot 7(2 \cdot 5)$ & $+8 \cdot 5(1.9)$ \\
\hline
\end{tabular}

A highly significant relation between the pretreatment height velocity SDS and change in height velocity SDS (fig $2, \mathrm{r}=0 \cdot 60, \mathrm{p}<0 \cdot 001$ ) was expressed by the formula: $y=2 \cdot 22-1 \cdot 28 x$. Where $y$ is the change in height velocity SDS and $x$ the pretreatment height velocity SDS. The remaining parameters did not significantly strengthen the relation.

The median weekly dose of growth hormone was $15 \mathrm{IU} / \mathrm{m}^{2} /$ week (range 11-36). An arbitrary cut off at $15 \mathrm{IU} / \mathrm{m}^{2} /$ week was used to examine the influence of dose on the growth response more closely. There was a significant difference between the regression slopes for the pretreatment height velocity SDS and change in height velocity S $\overline{D S}$ for children receiving more or less than $15 \mathrm{IU}$ growth hormone $/ \mathrm{m}^{2} /$ week $(p<0 \cdot 01)$. Table 2 shows the effect of receiving more or less than $15 \mathrm{IU} / \mathrm{m}^{2} /$ week within three subdivisions of pretreatment height velocity SDS reflecting differing degrees of growth hormone insufficiency.

Plasma concentrations of insulin like growth factor rose to within the normal range for age in most children during treatment. There was no difference in the concentrations of insulin like growth factor between the three groups either before or after growth hormone and they had no predictive value in determining the growth response to growth hormone.

\section{Discussion}

Insufficient growth hormone secretion severely compromises a child's final adult height and there are several reports of the final height achieved after growth hormone replacement. ${ }^{78}$ Although growth hormone can correct a failing growth rate, the final outcome of treatment cannot be regarded as completely successful because mean final heights achieved have been between -2 and -3.3 SDs from the population mean. At best only $50 \%$ of patients attained a final height within $2 \mathrm{SD}$ of their target height. ${ }^{78}$ Close comparison of the studies is difficult due to variation of subjects and different treatment schedules. The results show, however, that final height potential has been irretrievably lost before growth hormone treatment has been instituted; treatment simply preserves what height potential remains but cannot improve it. Thus one would predict that the earlier treatment was introduced and the less the height deficit at that time, the better would be the end result. A growth hormone insufficient child treated from birth would grow normally and we have observed children with congenital hypopituitarism treated with growth hormone from shortly after birth to grow at a normal velocity.

Joss et al showed a significant correlation between outcome and the growth velocity in the first year of growth hormone treatment but did not relate the response to the growth hormone regimen employed. ${ }^{7}$ The aim of our study was to investigate the factors that may influence the growth response during the first year of growth hormone treatment. This is the first report investigating the contribution of dose, frequency of growth hormone administration, and pretreatment auxological parameters to the therapeutic effect of Somatrem.

All the children showed an improvement in growth velocity in the first year of treatment. The children receiving the higher frequency regimens had the greatest improvement in growth rate, confirming the work of Albertsson-Wikland et al. ${ }^{9} 10$ Although frequency of administration was an influencing factor in the growth response to growth hormone, the magnitude of response was primarily determined by the pretreatment height velocity SDS and the dose $/ \mathrm{m}^{2} /$ week of growth hormone administered. This is in agreement with the study of pituitary growth hormone of Tanner et $a l^{1}$ and would be predicted by the asymptotic relation we have shown between growth hormone secretion and height velocity. ${ }^{12} 15$ Our results also show that a dose of at least $15 \mathrm{IU}$ growth hormone $/ \mathrm{m}^{2} /$ week is required to optimise the growth response observed. Different patient selection, availability of pretreatment auxological data, varying dose, and the regimens employed in previous studies make comparison of the contribution of dose between studies difficult. $^{1-8}$ 
The United Kingdom Medical Research Council working party concluded that an acceptable cost benefit ratio in the treatment of growth hormone insufficient children was achieved on a weekly dose of 12 IU human growth hormone in three equally divided intramuscular injections. ${ }^{5} \mathrm{~A}$ standard dose does not take into account the difference in surface area of the developing child or the observation that growth hormone secretion increases with age and pubertal development. ${ }^{13} 14$

These data taken in conjunction with known results of final height after growth hormone treatment strongly emphasise the importance of early diagnosis and therapeutic intervention before longstanding growth hormone insufficiency severely compromises the growth potential of the affected child. Therefore although the intial growth acceleration on growth hormone is less noticeable in the less severely affected child the final outcome will be more satisfactory.

We recommend earlier recognition of growth failure due to growth hormone insufficiency by use of height velocity charts and prompt treatment with growth hormone before height has fallen below the 3rd centile. The dose should be maintained at not less than 15 IU growth hormone $/ \mathrm{m}^{2} /$ week throughout childhood and should be administered by equally divided daily subcutaneous injections.

We thank Children Nationwide Medical Research Fund for financial support and Dr D Teale, St Luke's Hospital, Guildford, for measurement of the insulin like growth factor concentrations.

\section{References}

${ }^{1}$ Tanner JM, Whitehouse RH, Hughes PCR, Vince FP. Effect of human growth hormone treatment for one seven years on growth hormone of 100 children, with growth hormone deficiency, low birth weight, inherited smallness, Turner's syndrome and other complaints. Arch Dis Child 1971;46: 745-82.

2 Preece MA, Tanner JM, Whitehouse RH, Cameron A. Dose dependence of growth response to human growth hormone in growth hormone deficiency. $J$ Clin Endocrinol Metab 1975;42:477-83.

${ }^{3}$ Frasier SD, Aceto T Jr, Hayles AB, Mikity VT. Collaborative study of the effects of human growth hormone in growth hormone deficiency: 4. Treatment with low doses of human growth hormone based on body weight. J Clin Endocrinol Metab 1977;44:22-33.
${ }^{4}$ Frasier SD, Costin G, Lippe BN, Aceto $\mathrm{T} \mathrm{Jr}$, Bunger PS. A dose response curve to human growth hormone. J Clin Endocrinol Metab 1981;53:1213-7.

5 Milner RDG, Russell-Fraser T, Brook CGD et al. Experience with human growth hormone in Great Britain; the report of the MRC working party. Clin Endocrinol (Oxf) 1979;11:15-38.

6 Aceto T Jr, Frasier SD, Hayles AB, et al. Collaborative study of the effects of human growth hormone in growth hormone deficiency. 1. First year of therapy. J Clin Endocrinol Metab 1972;35:483-9.

7 Joss E, Zuppinger K, Schwarz HP, Roten H. Final height of patients with pituitary growth failure and changes in growth variables after long term hormonal therapy. Pediatr Res 1983; 17:676-9.

${ }^{8}$ Burns C, Tanner JM, Preece MA, Cameron N. Final height and pubertal development in 55 children with idiopathic growth hormone deficiency, treated for between 2 and 15 years with human growth hormone. Eur J Pediatr 1981;137:155-64.

9 Albertsson-Wikland K, Westphal A, Westgren U. Daily subcutaneous administration of human growth hormone in growth hormone deficient children. Acta Paediatr Scand 1986;75:89-97.

10 Albertsson-Wikland K. Growth hormone treatment in short children. Acta Paediatr Scand 1986;325(suppl):64-70.

11 Smith PJ, Pringle PJ, Brook CGD. Single dose and pulsatile treatment with human growth hormone multiple pulses of growth hormone $(\mathrm{GH})$ in the treatment of GH deficiency. Arch Dis Child 1987;62:849-51.

12 Brook CGD, Hindmarsh PC, Smith PJ. Is growth hormone deficiency a useful diagnosis? Acta Paediatr Scand 1987; 331(suppl): 70-5.

13 Parker DC, Rossman LG, Kripke FD, Gibson W, Wilson K. Rhythmicities in human growth hormone concentrations in the plasma. In: Krieger D, ed. Endocrine rhythms. New York: Raven Press, 1979:143-73.

${ }^{14}$ Mauras N, Blizzard RM, Link K, Johnson ML, Rogol AD, Veldhuis JD. Augmentation of growth hormone secretion during puberty: evidence for a pulse amplitude modulated phenomenon. J Clin Endocrinol Metab 1987;64:596-601.

15 Hindmarsh PC, Smith PJ, Brook CGD, Matthews DR. The relationship between height velocity and growth hormone secretion in short prepubertal children. Clin Endocrinol (Oxf) 1987;27:581-91.

16 Brook CGD. Growth assessment in childhood and adolescence. Oxford: Blackwell Scientific Publications, 1982.

17 Tanner JM, Whitehouse RH, Cameron NC, Marshall WA, Healy MJR, Goldstein H. Assessment of skeletal maturity and prediction of adult height (TW2). London: Academic Press, 1983.

18 Tanner JM, Whitehouse RH, Takaishi M. Standards from birth to maturity for height, weight, height velocity and weight velocity: British children. Arch Dis Child 1966;41:613-35.

19 Baxter RC, Brown SA, Turtle JR. Radioimmunoassay for somatomedin C: comparison with radioreceptor assay in patients with growth hormone disorders, hypothyroidism and renal failure. Clin Chem 1982;28:488-95.

Correspondence to Dr CGD Brook, Endocrine Unit, Middlesex Hospital, Mortimer Street, London W1N 8AA.

Accepted 27 November 1987 